\title{
ELVÁLASZTÁSI MÜVELETEK ÉS AZOK BERENDEZÉSEINEK VIZSGÁLATA
}

\author{
Kállai Viktória \\ PhD-hallgató, Miskolci Egyetem, Energetikai és Vegyipari Gépészeti Intézet \\ Vegyipari Gépészeti Intézeti Tanszék \\ 3515 Miskolc, Miskolc-Egyetemváros, e-mail: kallai@uni-miskolc.hu \\ Szepesi L. Gábor \\ egyetemi docens, Miskolci Egyetem, Energetikai és Vegyipari Gépészeti Intézet \\ Vegyipari Gépészeti Intézeti Tanszék \\ 3515 Miskolc, Miskolc-Egyetemváros, e-mail: szepesi@uni-miskolc.hu
}

\begin{abstract}
Absztrakt
A tanulmány célja alacsony szénatomszámú szénhidrogén elegyek desztillációs úton történö szétválasztásának vizsgálata és a gyakorlatban is alkalmazható megoldások keresése. Továbbá vizsgálatuk a nyomásveszteség értékét szita-és buboréksapkás tányérok alkalmazásakor. A kutatási idöszakban a szimulációk készitéséhez a Unisim Design folyamatszimulátor szoftvert használtuk.
\end{abstract}

Kulcsszavak: desztilláció, kolonna, paramétervizsgálat, nyomásveszteség

\section{Abstract}

The goal of the study is to investigate the separation of low carbon contents hydrocarbon mixtures by distillation and find solution which can be used in practise. Furthermore, a study was performed on the pressure loss when using sieve and bubble cap trays. To achieve the results, we used Unisim Design process simulator software.

Keywords: distillation, column, parametric investigation, pressure drop

\section{Bevezetés}

Ezen tanulmányban az elválasztási műveletek közül a desztillációt és az abszorpciót vizsgáltuk. A desztilláció a vegyipar és gyógyszeripar egyik leggyakrabban alkalmazott technológiája, amely gyakran hatalmas energiaszükséglettel rendelkezik [1]. A desztillációs folyamat során komponensek egymástól való elválasztását hajtják végre, az összetevők illékonyságbeli különbségét kihasználva. $\mathrm{Az}$ abszorpció művelete esetén egy gázelegy valamely komponensét nyeletik el folyadékfázisban.

Desztillációhoz és abszorpcióhoz alkalmazott berendezés az úgynevezett kolonna (vagy oszlop, torony), amelyben az áramlási viszonyok a szerkezeti kialakítástól függenek, emiatt a berendezések átméröjének és belső szerkezetének méretezése, ellenőrzése hidraulikai számításokon alapul. A számításokkal meghatározhatók a szükséges gőz- és folyadékkapacitások, azaz a terhelehetőségek, ezen túl ellenőrizhető, hogy az előzetesen kialakított belső elemek, azok elrendezése lehetővé teszi-e a kívánt szétválasztás megvalósítását [2].

A térségünkben található vegyipari komplexumokban is megtalálható technológiákat vizsgáltunk: elvégeztük az etán-etilén és propán-propilén szétválasztás paramétervizsgálatát, illetve különbözö tányérkonstrukciók nyomásveszteségével foglalkoztunk. 


\section{Paramétervizsgálatok}

A vizsgált müveletekben az etilén, illetve a propilén a fejtermékek, ezeket polimerizációs eljárásoknak vetik alá, és a müanyagok alapanyagaként alkalmazzák. A fenéktermékként kapott etán, illetve propán hütőközegként alkalmazható, valamint a folyamat elején repirolizálás után felhasználásra kerülnek. [3] Az olefin üzemek termékeként kapott etilén és propilén esetén a további felhasználásnál meghatározó a minőségük, ezért a legtisztább fejtermék kihozatalokra kell törekedni és az elvégzett paramétervizsgálatoknak is ez a célja. Az alacsony szénatomszámú szénhidrogének ideális elegyeknek tekinthetők [4], a vizsgálatok során ezt a szakirodalmi megállapítást érvényesnek tekintettük.

A tanulmányban bemutatott vizsgálatok Unisim Design [5] folyamatszimulátor szoftver használatával készültek, SRK [6] anyagmodell alkalmazásával.

\subsection{Etán-etilén elválasztás}

Az etilén és etán elválasztáshoz legelterjedtebben alkalmazott szeparációs eljárás a rektifikálás [4]. A szétválasztandó komponensek alacsony forráspontja miatt nagynyomású, kriogén körülményeket szükséges alkalmazni, hogy a szétválasztás során megfelelő minőségü termékek álljanak rendelkezésre.

A vizsgált rektifikáló oszlop $45 \mathrm{db}$ szitatányérral rendelkezik, amelyek között $0,4 \mathrm{~m}$ a tányértávolság és az oszlop $2 \mathrm{~m}$ átmérőjü. A betáplálás a kolonna 40. tányérjára (ha a tányérok számozása fentről lefelé történik) érkezik gőzfázisként. A kiindulási modellben a reflux arány értéke 3, a fejtermék mennyisége $20000 \mathrm{~kg} / \mathrm{h}$, amely technológiai alapadat. Az 1. táblázat tartalmazza a kolonnába belépő és onnan távozó anyagáramok paramétereit.

1. táblázat. Etán-etilén elválasztó kolonna betáplálásának és termékeinek paraméterei

\begin{tabular}{|l|c|c|c|}
\hline Paraméterek & Betáplálás & Fejtermék & Fenéktermék \\
\hline Hőmérséklet $\left[{ }^{\circ} \mathbf{C}\right]$ & $-60,2$ & $-70,92$ & $-54,55$ \\
\hline Nyomás [bar] & 6 & 5 & 5 \\
\hline Tömegáram [kg/h] & 30000 & 20000 & 10000 \\
\hline Összetétel [n/n\%] & & & 5,95 \\
\hline Etilén & 70 & 99,99 & 94,05 \\
\hline Etán & 30 & 0,01 & \\
\hline
\end{tabular}

A vizsgálat célja maximális fejtermékbeli etilén tisztaság elérése minimális energia felhasználása mellett (mivel a fejtermék összetétele hatással van a kondenzátor energiaigényére). A betáplálás pozíciójának, a reflux aránynak és a nyomás változtatásának hatását vizsgáltuk.

A betáplálás helyének változtatása esetén a szimuláció eredményeiből megállapítható, hogy a legnagyobb etilén tisztaság a fejtermékben a 38-39. tányérra történő betáplálással érhető el. $\mathrm{Az}$ is kiderült, hogy a 30-41 tartományba eső tányérok bármelyikére vezetve a betáplálási áramot a kívánt tisztaságú desztillátumot kapjuk.

Egy rektifikáló oszlop paraméterei közül a nyomás igen meghatározó paraméter. Megvizsgálva különböző nyomásértékeknél a kolonna más paramétereit megállapítható, hogy 3-6 bar nyomású betáplálás esetén érhetö el az etilénben legtisztább fejtermék. A nyomás és hőmérséklet közötti kapcsolat miatt a nyomás növelésével csökkenni fog a kiforraló és a kondenzátor höigénye.

Egy kolonna szintén jelentős paramétere a kihozatali termékek szempontjából a reflux arány, amelynek nagysága szoros kapcsolatban áll a kondenzátor teljesítményének és a kolonna átméröjének nagyságával. Ha növeljük a reflux arányt, akkor a kondenzátor energia igénye és a kolonna átméröje is nőni fog. A vizsgálat elején meghatározott elérni kívánt etilén mólszázalék a fejtermékben 99,99\% volt, 
amely már 2,8-as reflux aránnyal is elérhető, így az optimális energiafelhasználás érdekében erre az értékre ajánlott beállítani a reflux arányt. Továbbá az is megállapítható, hogy ennél nagyobb reflux arány értékkel sem nő számottevő mértékben a fejtermék tisztasága, azonban a kondenzátor energiaigénye és a reflux arány értéke között lineáris kapcsolat van.

Az etán-etilén kolonnán végzett paramétervizsgálat eredményeiböl meghatározhatóak a kolonna optimális paraméterei, azaz a betáplálás a 38. tányérra érkezzen, a nyomása 6 bar legyen és 2,8-as reflux arányt szükséges alkalmazni. Ebben az esetben 99,99\% tisztaságú etilén nyerhető ki fejtermékként.

\subsection{Propán-propilén elválasztás}

A propán-propilén komponensek illékonysága közötti különbség igen kicsi, ez abból adódik, hogy a forráspontjaik között a különbség csak $5,5{ }^{\circ} \mathrm{C}$. Ezért az elválasztásuk rendkívül energiaigényes technológia [7]. Mivel szintén a vegyipar egyik jelentős alapanyagáról van szó, ezért ebben az esetben is nagy tisztaságú (és mennyiségü) fejtermék elérésére kell törekedni. A paramétervizsgálat célja ebben az esetben is a fejtermék szükséges minőségének elérése és az energiafelhasználás csökkentése.

Az elválasztáshoz nagy nyomású desztillációt alkalmaznak, a berendezés pedig közel 200 tányért tartalmazó kolonna. Mivel ez hatalmas oszlopot jelent, ezért a gyakorlatban fizikailag két külön kolonnát alkalmaznak, amelyek kialakításukat és a folyamat lejátszódását tekintve egyként kezelendők.

A kolonna kialakítását leíró geometriai és technológiai alapadatokat, valamint a betáplálás paramétereit a 2. táblázat foglalja össze.

2. táblázat. A kolonna és a betáp és termék áramok paraméterei

\begin{tabular}{|l|c|l|c|c|c|}
\hline \multicolumn{2}{|c|}{ Kolonna } & & Betáp áram & Fejtermék & Maradék \\
\hline Tányérok száma, típusa & 183, szita & Hömérséklet [ $\left.{ }^{\circ} \mathbf{C}\right]$ & 52,58 & 46,65 & 57,29 \\
\hline Oszlopátmérő [m] & 4,5 & Nyomás [bar] & 20,68 & 19,31 & 20,68 \\
\hline Tányértávolság [m] & 0,45 & Tömegáram [kmol/h] & 612,4 & 351,5 & 260,9 \\
\hline Betáplálás helye* & 136. tányér & Összetétel [n/n\%] & & & \\
\hline Reflux arány & 16,4 & Propilén & 60 & 98,95 & 7,51 \\
\hline Kolonnanyomás [bar] & 20 & Propán & 40 & 1,05 & 92,49 \\
\hline
\end{tabular}

*: Ha a tányérok számozása fentről lefelé történik.

A szimuláció eredménye alapján a kondenzátornak 20,77 MW, míg a kiforralónak 18,74 MW az energiaigénye.

A paramétervizsgálat során a betáplálás helyének, a kolonnanyomásnak és a reflux aránynak a módosításából adódó változásokat vizsgáltuk.

Betáplálás pozíciójának változtatása esetén a szimulációk eredményeként megállapítható, hogy a 100. és 160. tányérok közé helyezve a betáplálási áramot, a legtisztább fejtermék érhető el, míg a kondenzátor energiaárama a 153. és 155. tányérok történő betáplálás esetén a legkisebb.

A kolonna nyomásának változtatását 1,5 és 25 bar értékek között végeztük. Az eredmények azt mutatják, hogy a kolonna nyomásának nincs jelentős befolyásoló hatása a fejtermék propilén móltörtjére, illetve a kondenzátor höáramára. A hőmérséklet és nyomás közötti kapcsolat miatt, alacsonyabb nyomáson történő betáplálás esetén kriogén desztilláció játszódik le, amely a kiforralóban nagyobb energiaszükségletet okoz.

A reflux arány értékét 5 és 25 között változtattuk. A reflux arány és a kondenzátor hőárama között lineáris kapcsolat van. A szimulációk eredményei alapján megállapítható, hogy 15,2-nél nagyobb reflux arány esetén nem tapasztalható számottevő változás a fejtermék propilén móltörtjében, azonban a kondenzátor hőárama igen nagy mértékben megnő. 15,2 reflux arány esetén a fejtermékben $98,055 \mathrm{n} / \mathrm{n} \%$ 
propilén található, és a kondenzátor hőárama 19,35 MW. Ez a változás azt jelenti, hogy az eredeti rendszerhez képest a fejtermék propilén tisztasága 0,855 \%-kal, míg a kondenzátor hőárama 1,43 MWtal csökkent.

A paramétervizsgálat eredményeiből megállapítható, hogy kisebb módosításokkal elérhető egy kedvezőbb energia felhasználású, és közel azonos tisztaságú fejterméket adó rendszer. Ehhez vagy a betáplálás helyét vagy a reflux arányt szükséges módosítani. A fent említett változtatásokat és a vizsgált paraméterekre így kapott értékeket a 3. táblázat foglalja össze.

3. táblázat. A vizsgált paraméterek az eredeti és módositott modellek esetén

\begin{tabular}{|c|c|c|c|}
\hline & $\begin{array}{c}\text { Eredeti } \\
\text { modell }\end{array}$ & $\begin{array}{c}\text { Betáplálás helyének } \\
\text { változtatása (155. fokozat) }\end{array}$ & $\begin{array}{c}\text { Módosított reflux } \\
\text { arány (15,2) }\end{array}$ \\
\hline Propilén móltörtje a fejtermékben & 0,9895 & 0,9813 & 0,98055 \\
\hline Kondenzátor hőárama [MW] & 20,77 & 20,75 & 19,35 \\
\hline
\end{tabular}

\section{Tányér hidraulika}

A müködés során az oszlop mentén kialakul egy nyomásgradiens - különben a gőzfázis nem tudna felfelé áramolni. Ezt a nyomásgradienst általában tányéronkénti nyomáseséssel fejezik ki [8].

Egy tányér hidrodinamikai tervezése igen lényeges eleme a torony tervezésének. A kolonna, valamint a tányér is meghatározott müködési tartománnyal rendelkeznek. A tartomány határain való átlépés a müködés és az elválasztás hatásfokának drasztikus csökkenését okozza [9].

Túlfolyós tányéros kolonnákban a folyadék a gőzfázissal keresztáramban halad lefelé egyik tányérról a másikra, miközben a kevésbé illékony komponensben dúsul. A tányéron lévő folyadék magasságát a kilépő élen elhelyezett gát magassága szabja meg. A gőzfázis a folyadékfázisba buborékol a tányér perforációin keresztül szitatányér esetén. Míg buboréksapkás tányéroknál az ún. kéményen elhelyezett buboréksapka perforációin keresztül buborékol a gőz- vagy gázfázis a folyadékfázisba [9].

A tanulmány során két gyakran alkalmazott tányértípus vizsgálatára került sor: a szita - és buboréksapkás tányérok. Ezek a legrégebbi tányértípusok közé tartoznak és széleskörü alkalmazással rendelkeznek.

Egy tányér nyomásesése a tányér felett és alatt lévő gőzfázisok nyomása közötti különbséget jelenti. Egy kolonna teljes nyomásesése az egyes tányérokon kialakuló nyomáskülönbségek összegét jelenti. A nyomás a következő kolonna paramétereket befolyásolja:

- hőmérséklet profil,

- gőz-folyadék egyensúly,

- gőzterhelés, mivel a gőzsürüsége függ a nyomástól és a hőmérséklettől.

Szem előtt kell tartani, hogy egy tányér nyomásesése kisebb kell, hogy legyen, mint a folyadékfázis statikus nyomása a túlfolyóban (lefolyóban), ellenkező esetben a gőzfázis vissza tudná nyomni a folyadékot a lefolyóban és az nem tudna lefelé haladni. [10], [11]

\section{A vizsgált rendszer és a megalkotott modell}

A vizsgált rendszer: ammóniával szennyezett levegő, amelyet vízzel kell megtisztítani. Az ammónia az egyik legjobban vízben oldódó gáz.

Mivel a gázok oldhatósága a hömérséklet növelésével csökken, ezért minél alacsonyabb hömérsékleten szükséges az abszorpció folyamatát végrehajtani. Ezen kívül a nagyobb nyomás kedvez az abszorpció lejátszódásának [12]. 
A szimulációk elkészítéséhez Unisim Design [5] szoftvert alkalmaztuk SourSRK [13], [14] anyagmodellel. Az oszlopban 10 darab tányér került beépítésre, az alkalmazott tányértávolság $500 \mathrm{~mm}$, az oszlopátmérő pedig $0,8 \mathrm{~m}$ volt. A 4 . táblázat tartalmazza a betáplálások és a kapott termékek paramétereit. A betáplált anyagáramok nyomása 6,2 bar volt. Megfigyelhető, hogy az ammónia vízben való oldódása hővel jár, azaz a közeg felmelegedett $15^{\circ} \mathrm{C}$-ról $27^{\circ} \mathrm{C}$-ra.

A számításokat a [15] irodalom alapján készítettük el. A számítás során nyomásveszteségek meghatározásához mindkét esetben direkt vagy indirekt módon szükség van a fokozatokra és a fokozatokról távozó anyagáramok sűrűség értékeire. A szitatányér esetén a gőzfázis sűrűsége a száraz nyomásveszteség kiszámításához alkalmazandó egyszeres hatvánnyal, míg a folyadék sürüsége a tányér nyomásveszteség meghatározásához alkalmazott képlet második tagjában szerepel szintén egyszeres szorzóval. Buboréksapkás tányér esetén mindkét sürüség tag szerepel a sapka parciális nyomásveszteségének meghatározásához szükséges képletben, a résnyitásból eredő nyomásveszteség képletében, valamint szükségesek még a folyadékgradiens meghatározásához is.

4. táblázat. A rendszer anyagáramainak paraméterei

\begin{tabular}{|l|c|c|c|c|}
\hline Anyagáram neve & Víz & Ammónia + levegö & Tisztított levegö & Szennyezett víz \\
\hline Hömérséklet $\left[{ }^{\circ} \mathbf{C}\right]$ & 15 & 10 & 15 & 27,04 \\
\hline Tömegáram [kg/h] & 15000 & 7000 & 6581,8 & 15418,2 \\
\hline \multicolumn{5}{|c|}{ Összetétel [n/n] } \\
\hline Víz & 1 & 0 & 0,003 & 0,97 \\
\hline Levegö & 0 & 0,9 & 0,997 & 0 \\
\hline Ammónia & 0 & 0,1 & 0 & 0,03 \\
\hline
\end{tabular}

Mivel tányérról-tányérra változik az összetétel ezért a sürüség és a tömegáram is változni fog. A tányérok számozása az oszlopban fentről lefelé történik. A víz az első, a levegő és ammónia keverék pedig a tizedik tányérra érkezik.

Az eredményekből elmondható, hogy a számítás eredménye jól közelíti a szimuláció eredményét: egy tányér esetén maximum buboréksapkás tányér esetén 0,03 , míg szitatányér esetén 0,006 különbség figyelhető meg. Továbbá az is látható, hogy a buboréksapkás tányérokon adódó nyomásveszteségek körülbelül kétszeresei a szitatányéron eső nyomásveszteség értékeknek.

5. táblázat. Az oszlop teljes nyomásvesztesége a különbözö esetekben

\begin{tabular}{|c|c|c|}
\hline Nyomásveszteség & Számítás & Szimuláció \\
\hline Tányértípus & $12,58 \mathrm{kPa}$ & $12,35 \mathrm{kPa}$ \\
\hline Buboréksapkás tányér & $5,22 \mathrm{kPa}$ & $5,27 \mathrm{kPa}$ \\
\hline
\end{tabular}

Az 5. táblázatban összefoglalva láthatók a teljes kolonnára érvényes nyomásveszteségek számítás és szimuláció esetén mindkét tányértípusra. Az eredményekből látható, hogy a két módszer eredményei közötti különbség nem jelentős.

\section{5. Összefoglalás}

A paramétervizsgálatokból adódóan meghatározható a fejtermék tisztasága és a technológia energiafelhasználásának minimalizálása szempontjából egy optimális megoldás, amely a tanulmányban vizsgált üzemi paraméterek kismértékủ változtatását jelenti és a gyakorlatban is megvalósítható. 
A buboréksapkás tányér egy sokkal összetettebb konstrukció, mint a szitatányér. A számítások és szimulációk eredményeit összevetve megállapítható, hogy a szitatányérokon eső nyomásveszteség a folyamat során körülbelül fele akkora, mint a buboréksapkás tányérok esetén. A folyamat lejátszódása szempontjából mindkét tányértípusnál elérhető a kívánt levegő tisztaság értéke, azaz a víz képes az összes ammóniát elnyelni megtisztítva ezzel a levegőt.

\section{Köszönetnyilvánítás}

A cikkben ismertetett kutató munka az EFOP-3.6.1-16-2016-00011 jelü „Fiatalodó és Megújuló Egyetem - Innovatív Tudásváros - a Miskolci Egyetem intelligens szakosodást szolgáló intézményi fejlesztése" projekt részeként - a Széchenyi 2020 keretében - az Európai Unió támogatásával, az Európai Szociális Alap társfinanszírozásával valósul meg.

\section{Irodalom}

[1] Annakou, O., Mizsey, P.: Rigorous investigation of heat pump assisted distillation, Heat Recover. $\begin{array}{lllllll}\text { Syst. } & \text { CHP, } & \text { vol. } & 15, \quad \text { no. } 3,-247 .\end{array}$ https://doi.org/10.1016/0890-4332(95)90008-X

[2] Fonyó, Z., Fábry, G.: Vegyipari müvelettani alapismeretek, Nemzeti Tankönyvkiadó Rt., 2004.

[3] Benali, M., Aydin, B.: Ethane/ethylene and propane/propylene separation in hybrid membrane distillation systems: Optimization and economic analysis, Sep. Purif. Technol., vol. 73, no. 3, (2010) pp. 377-390. https://doi.org/10.1016/j.seppur.2010.04.027

[4] Soave, G. S., Gamba, S., Pellegrini, L. A., Bonomi, S.: Feed-splitting technique in cryogenic distillation, Ind. Eng. Chem. Res., vol. 45, no. 16, (2006) pp. 5761-5765. https://doi.org/10.1021/ie051343e

[5] UniSim ${ }^{\circledR}$ Design User Guide, "User Guide."

[6] Jaubert, J. N., Privat, R.: Relationship between the binary interaction parameters (kij) of the PengRobinson and those of the Soave-Redlich-Kwong equations of state: Application to the definition of the PR2SRK model, Fluid Phase Equilib., vol. 295, no. 1, (2010) pp. 26-37. https://doi.org/10.1016/j.fluid.2010.03.037

[7] Alcántara-Avila, J. R., Gómez-Castro, F. I., Segovia-Hernández, J. G., Sotowa, K.-I., Horikawa, T.: Chemical Engineering and Processing : Process Intensification Optimal design of cryogenic distillation columns with side heat pumps for the propylene / propane separation, Chem. Eng. Process. Process Intensif., vol. 82, (2014) pp. 112-122.

https://doi.org/10.1016/j.cep.2014.06.006

[8] http://facstaff.cbu.edu/rprice/lectures/distill.html

[9] Gamse, T.: Hydrodynamic layout of columns, Graz: Graz University of Technology, 2004.

[10] Kafarov, V. V.: Az anyagátadás alapjai, Budapest, Müszaki Könyvkiadó, 1967.

[11] Fábry, G.: Vegyipari gépek és müveletek VII., Budapest, Tankönyvkiadó, 1980.

[12] Rácz, I.: Vizkémia II., Szent István Egyetem, 2011.

[13] https://www.pidesign.co.uk/

[14] https://www.chemicalprocessing.com/assets/Media/MediaManager/thermo.pdf

[15] Dullien, F., Máthé, L., Paál, T., Vincze, L.: Diffúziós müveletek, Budapest, Vegyterv Müszaki Főosztálya, 1970. 